\title{
Sorption of Copper Ions from the Nitric Acid Solution of Electrolytic Refining of Silver with Using Chelating Resin Axionit BPA
}

\author{
Sergey A. Aleynikov*a, \\ Ilya V. Ponomarenko a and G. A. Sorkinova ${ }^{\text {b }}$ \\ a JSC «Axion - Rare and Noble Metals» \\ Perm, Russian Federation \\ ${ }^{b}$ Siberian Federal University \\ Krasnoyarsk, Russian Federation
}

Received 09.03.2021, received in revised form 15.11.2021, accepted 13.01.2022

\begin{abstract}
The article considers a sorption method for extracting copper ions from a model nitric acid solution based on a solution of electrolytic refining of silver with using sorbents with bis-picolylamine functional groups: Dowex M-4195 and AXIONIT BPA. The possibility of extracting copper to residual concentrations in the solution of less than $10 \mathrm{mg} / \mathrm{l}$ is shown. The working capacity of both samples under batch conditions, as well as the dynamic exchange capacity and the full dynamic exchange capacity under dynamic conditions (column test), are determined. The effect of the flow rate of the solution into the column on the kinetics of the sorption of copper ions on AXIONIT BPA is shown. The possibility of desorption of copper with a solution of $3 \%, 5 \% \mathrm{NH}_{4} \mathrm{OH}$ was investigated, and a two-stage scheme of desorption of copper was tested: $5 \%$ and $10 \%$ with a solution of ammonium hydroxide.
\end{abstract}

Keywords: sorption, copper, electrolyte, desorption.

Citation: Aleynikov, S. A., Ponomarenko, I. V., Sorkinova G. A. Sorption of copper ions from the nitric acid solution of electrolytic refining of silver with using chelating resin Axionit BPA. J. Sib. Fed. Univ. Chem., 2022, 15(1), 45-56. DOI: 10.17516/19982836-0270

(C) Siberian Federal University. All rights reserved

This work is licensed under a Creative Commons Attribution-NonCommercial 4.0 International License (CC BY-NC 4.0).

* Corresponding author E-mail address: saaleynikov@yandex.ru 


\title{
Сорбция ионов меди из азотнокислого раствора \\ электролитического рафинирования серебра \\ на хелатирующую смолу Axionit BPA
}

\author{
С.А. Алейников ${ }^{a}$, \\ И. В. Пономаренко ${ }^{a}$, Г. А. Соркинова ${ }^{\sigma}$ \\ ${ }^{a}$ АО«Аксион - Редкие и Драгоченные Металль»» \\ Российская Федераичия, Пермь \\ ${ }^{6}$ Сибирский федеральный университет \\ Российская Федерация, Красноярск
}

\begin{abstract}
Аннотация. В статье рассмотрен сорбционный способ извлечения ионов меди из модельного азотнокислого раствора на основе электролитического рафинирования серебра на сорбенты с бис-пиколиламиновыми функциональными группами: Dowex M-4195 и AXIONIT BPA. Показана возможность извлечения меди до остаточных концентраций в растворе менее 10 мг/л. Определена рабочая емкость обоих образцов в статических условиях, а также динамическая обменная емкость и полная динамическая обменная емкость в динамических условиях. Показано влияние скорости подачи раствора в колонку на кинетику сорбции ионов меди на АХIONIT ВРА. Исследована возможность десорбции меди раствором $3 \%, 5 \% \mathrm{NH}_{4} \mathrm{OH}$, а также опробована двухстадийная схема десорбции меди: 5 \% и $10 \%$ раствором гидроксида аммония.
\end{abstract}

Ключевые слова: сорбция, медь, электролит, десорбция.

Цитирование: Алейников, С. А. Сорбция ионов меди из азотнокислого раствора электролитического рафинирования серебра на хелатирующую смолу Axionit BPA / С. А. Алейников, И. В. Пономаренко, Г. А. Соркинова // Журн. Сиб. федер. унта. Химия, 2022, 15(1). С. 45-56. DOI: 10.17516/1998-2836-0270

\section{Introduction}

According to [1] for 2015, almost $30 \%$ of the world's silver is mined incidentally from polymetallic ores. This type of raw material creates difficulties in obtaining refined silver, in particular, at the stage of electrolytic refining. The largest proportion of impurities in the silver electrolyte is copper. In small quantities, copper is not able to affect the technological parameters of silver electrolysis, however, with repeated using of the electrolyte, copper inevitably accumulates in the electrolyte and can significantly degrade the quality of the obtained silver, when copper concentration reaches critical level. One of the possible ways to remove copper from silver electrolyte is sorption.

It iswell known that sorbents with bis-picolylamine (BPA) functional groups are able to efficiently extract copper from neutral and acidic solutions [2], [3], [4]. The structure of the bis-picolylamine functional group is shown in Figure 1.

The sorption of copper ions on sorbents of this type occurs due to the formation of stable chelate complexes with bis-picolylamine functional groups. The reaction of sorption of copper from nitric acid solutions on BPA can be represented as follows: 


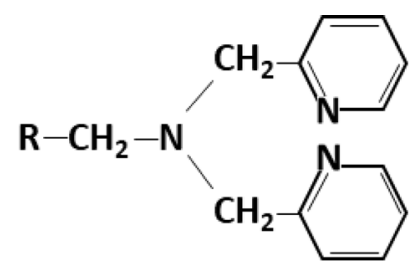

Fig. 1. Structure of the bis-picolylamine functional group

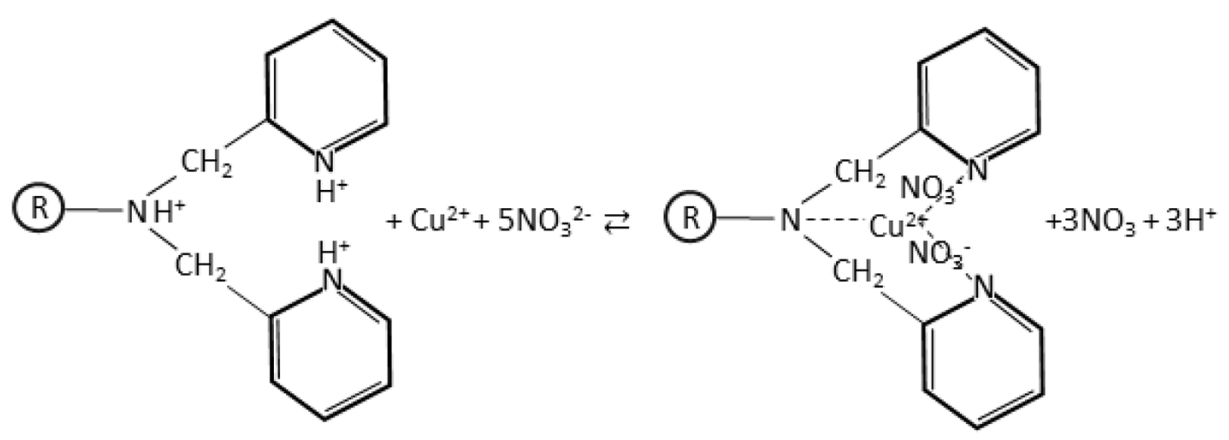

Fig. 2. Interactions of DowexM-4195 with $\mathrm{Cu}(\mathrm{II})(\mathrm{pH}=2)$ [2]

The feature of sorbents based on BPA is that even at low $\mathrm{pH}$ values, nitrogen atoms of pyridyl groups are not protonated, due to the low $\mathrm{pKa}=3.5$ [5], which makes it possible to extract copper from acidic solutions. Robert Grinstead [5] established the dependence of the absorption constant on the $\mathrm{pH}$ of the solution for some ions of transition metals, including copper (Fig. 3). As can be judged from the curve for copper (Fig. 3), the efficiency of sorption from solutions with $\mathrm{pH}<2$ decreases. In this regard, for the most complete removal of copper from acidic solutions, it is necessary to adjust the $\mathrm{pH}$ of the solution being purified.

Since ion exchangers with BPA functional groups are able to adsorb $\mathrm{Cu}$ (II) ions even from acidic solutions, copper desorption is possible only under conditions when a more stable complex is formed than $\mathrm{Cu}-\mathrm{BPA}$, or in a highly acidic medium, in which protonation of pyridine nitrogen is possible. In the first case, desorption is carried out with an ammonia solution due to the high stability of copper ammonia, and in the case of acidic desorption, sulfuric acid is usually used.

Sulfuric acid desorption involves the need to pass large volumes of $\mathrm{H}_{2} \mathrm{SO}_{4}$ solution for the most complete desorption. In [6], to achieve $99 \%$ of the degree of copper desorption, the consumption of $4 \mathrm{M}$ sulfuric acid was $30 \mathrm{ml}$ per $1 \mathrm{~g}$ of resin.The possibility of ammonia desorption of copper was shown in [7] and [8]. In [7], the desorption of copper from Dowex XFS 4195 was carried out with $2 \%$ ammonium hydroxide, while more than $90 \%$ of copper was desorbed while passing 15 column volumes of ammonia solution. The authors of [8] carried out a two-stage copper desorption with Dowex M-4195: first, $10 \mathrm{BV}$ of $1 \mathrm{M} \mathrm{H}_{2} \mathrm{SO}_{4}$ was passed, then $10 \mathrm{BV}$ of $4 \mathrm{M}(7 \%) \mathrm{NH}_{4} \mathrm{OH}$ at a flow rate about $2 \mathrm{BV} / \mathrm{h}$, while $99 \%$ of copper was desorbed. Desorption of copper by ammonium hydroxide solution is carried out according to the reaction (Fig. 4):

Under these conditions, stable copper tetraamine nitrate are formed, and nitrogen atoms are in the form of a free base and are not able to exchange ions. 


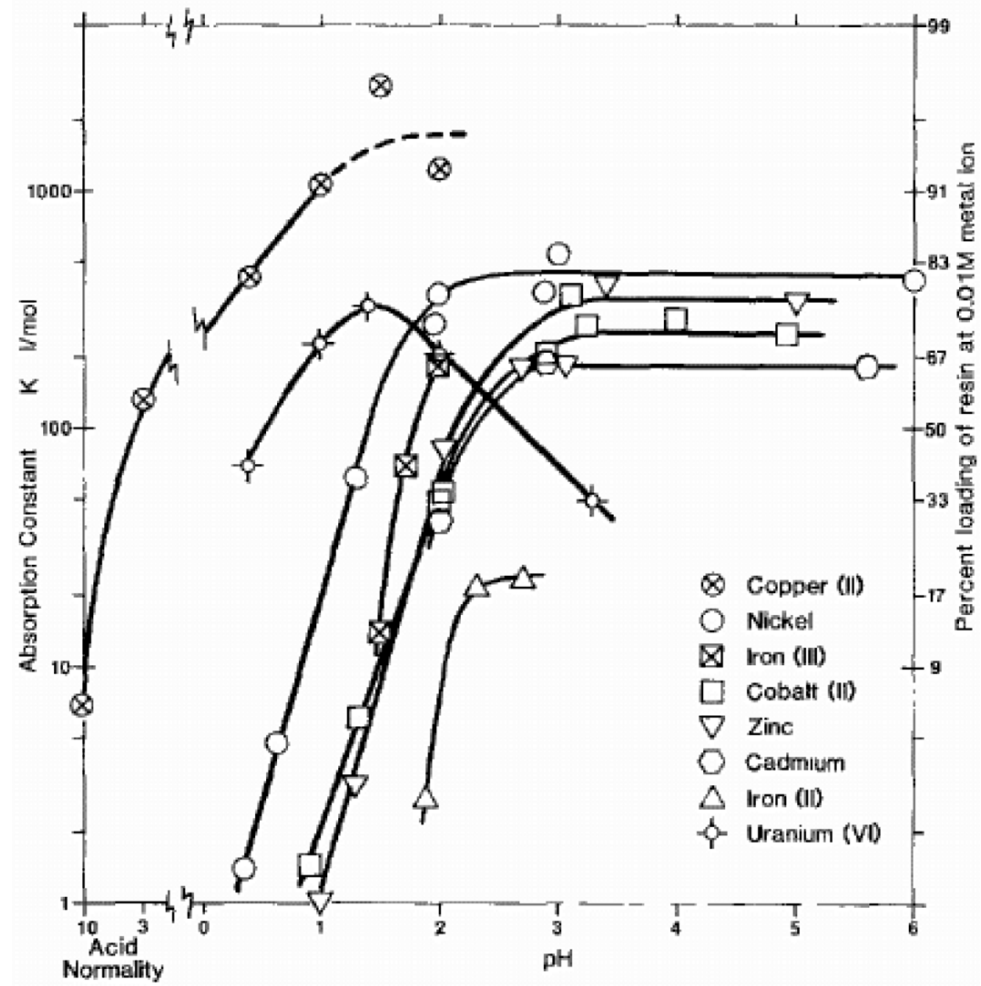

Fig. 3. pH-distribution profiles for XFS 4195 (M-4195)[5]

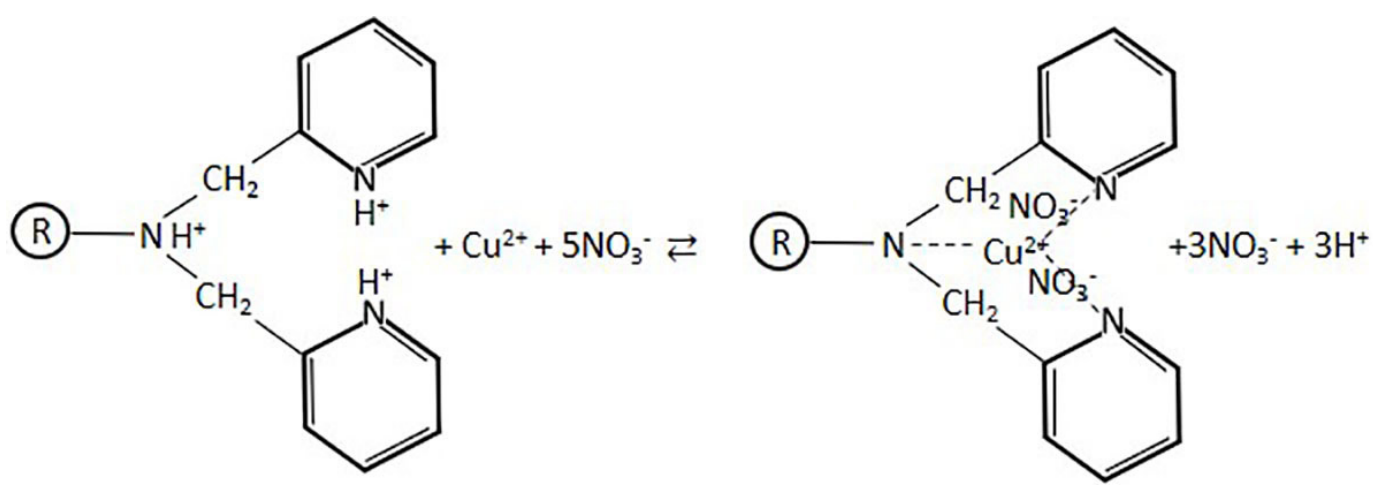

Fig. 4. Scheme of desorption of copper by ammonium hydroxide from BPA functional groups

The objectives of this work: to investigate the possibility of cleaning the silver electrolyte from copper ions by sorption on ionite with bis-picolylamine functional groups, to determine the capacity of the sorbent under static and dynamic conditions, to determine the coefficient of separation of copper and silver by sorption under dynamic conditions, to select the optimal parameters of sorption and desorption for a more complete separation of copper and silver. 


\section{Materials and methods}

To study the sorption of copper, we used sorbent samples with bis-picolylamine functional groups: DOWEX тм M-4195 (Dow Chemical Company, USA) and AXIONIT BPA (JSC «Axion - Rare and Noble Metals, Russia).

For experiments on saturation under batch and dynamic conditions, a model solution was prepared, simulating a silver electrolyte and containing copper and silver. The model solution was prepared by dissolving $\mathrm{AgNO}_{3}$ and $\mathrm{Cu}\left(\mathrm{NO}_{3}\right)_{2}$ in $4 \% \mathrm{HNO}_{3}$, and the $\mathrm{pH}$ of the solution was adjusted by the adding of dry $\mathrm{NaOH}$ to $\mathrm{pH}=2$.

The concentration of copper in solutions was measured by plasma atomic emission spectrometry (ICP-AES) on an iCAP RQ inductively coupled plasma atomic emission spectrometer (Thermo Fisher Scientific). In dynamic experiments for sorption and desorption of copper, Masterflex L/S7519-06 pump was used to supply the solution to the column, and a C660 fraction collector (Buchi) was used to collect the solution fractions. In experiments on the saturation of the sorbent under batch conditions, a Heidolph Vibramax 100 vibration shaker was used for constant stirring. And for weighing the sorbent weighed amount, a CAUW-220D analytical balance was used.

Staticbatch exchange capacity (SBEC) was calculated using the formula (1):

$$
S B E C=\frac{(\mathrm{C} 0-\mathrm{C} 1) \times V}{\text { Vresin }}, m g / m l
$$

where $\mathrm{C}_{0}$ - the initial concentration of the element in solution, $\mathrm{mg} / \mathrm{l} ; \mathrm{C}_{1}$ - equilibrium concentration of an element in solution, $\mathrm{mg} / \mathrm{l} ; \mathrm{V}_{\text {breakthrough }}$ - the volume of the solution, $1 ; \mathrm{V}_{\text {resin }}$ - the volume of the sorbent, $\mathrm{ml}$.

Dynamic exchange capacity (DEC) and full dynamic exchange capacity (FDEC) were calculated using formulas (2) and (3), respectively:

$$
D E C=\frac{\text { coxVbreakthrough }}{\text { Vresin }}, \mathrm{mg} / \mathrm{ml}
$$

where $\mathrm{C}_{0}$ - the initial concentration of the element in solution, $\mathrm{mg} / \mathrm{l} ; \mathrm{V}$ - the volume of the solution passed before the breakthrough, $1 ; \mathrm{V}_{\text {resin }}$ - the volume of the sorbent, $\mathrm{ml}$.

$$
F D E C=\frac{(\text { C } 0-\text { Cexit }) \times V}{\text { Vresin }}
$$

where $\mathrm{C}_{0}$ - the initial concentration of the element in solution, $\mathrm{mg} / \mathrm{l} ; \mathrm{S}_{\text {exit }}-$ the concentration of an element in the solution at the exit from the column, $\mathrm{mg} / \mathrm{l} ; \mathrm{V}-$ the volume of the solution, $1 ; \mathrm{V}_{\text {resin }}-$ the volume of the sorbent, $\mathrm{ml}$.

To determine the exact volume of the sorbent in experiments on copper sorption under batch conditions, the bulk density for AXIONIT BPA and Dowex M-4195 was preliminarily calculated using the formula (4):

$$
\rho \mathrm{H}=\frac{m}{\mathrm{~V}}, m g / m l
$$

where, $\mathrm{m}$ - the mass of the sorbent, $\mathrm{mg} ; \mathrm{V}$ - the volume of the sorbent, $\mathrm{ml}$

To assess the selectivity of the absorption of copper ions by the sorbent in the presence of silver ions, the separation coefficient calculated by the formula (5) was used:

$$
D_{C u, A g}=\frac{\mathrm{Kd}_{C u}-\frac{\bar{C}_{C u} C_{A g}}{\mathrm{Kd}_{A g}}}{\bar{C}_{A g} C_{C u}}
$$


where, $K d_{C u}$ и $K d_{A g}$ - distribution coefficients of copper and silver ions, respectively, between the sorbent-solution phases; $\bar{C}_{C u}$ и $\bar{C}_{A g}$ - the concentration of copper and silver ions, respectively, in the sorbent (desorbate); $C_{C u}$ и $C_{A g}$ - the concentration of copper and silver ions, respectively, in the initial solution.

\section{Experimental}

\section{Sorption under static batch conditions}

Sorption of copper under static conditions was carried out from a model solution (Table 1). A sample of each of the AXIONIT BPA and Dowex M-4195 sorbent samples was added to 4 flasks of $50 \mathrm{ml}$ filled with $25 \mathrm{ml}$ of the model solution. Saturation took place within 24 hours with constant stirring on a shaker. Based on the bulk density calculated by formula (4), the volume of each sample was determined. The solutions before and after saturation were analyzed for copper content, and the capacity was calculated using formula (1) based on the data obtained. The results of the experiment on the sorption of copper under static conditions are presented in Table 2.

\section{Sorption under dynamic conditions}

To measure the sorption characteristics of the sorbent under dynamic conditions, a column with a volume of $120 \mathrm{ml}$, IOK VZOR 30/24/300, was used, which was filled with $100 \mathrm{ml}$ of the sorbent for each sample. Since these sorbents are supplied in the form of a free base, a solution of $1 \mathrm{M} \mathrm{HNO}_{3}$ was passed through the column with a sample of the sorbent at a specific load of 3 column volumes per hour ( $3 \mathrm{BV} / \mathrm{h}$ ) to bring the sorbent into the $\mathrm{H}^{+}$form and for removing organic impurities.

The saturation of AXIONIT BPA and Dowex M-4195 in a comparative experiment was carried out from a model solution (Table 1) at a specific load of $1 \mathrm{BV} / \mathrm{h}$. To determine the effect of the solution feed rate into the column for copper sorption, an experiment for saturation of Axionit BPA was carried out at a specific load of 1 and $3 \mathrm{BV} / \mathrm{h}$. In all experiments the solution to be purified was fed into the column from the bottom.

Table 1. Model solution for copper sorption $(\mathrm{pH}=2)$

\begin{tabular}{|c|c|c|}
\hline \multicolumn{3}{|c|}{ Concentration, $\mathbf{g} / \mathbf{l}$} \\
\hline $\mathbf{A g}^{+}$ & $\mathbf{C u}^{2+}$ & $\mathbf{H N O}_{3}$ \\
\hline 180.0 & 13.0 & 20.0 \\
\hline
\end{tabular}

Table 2. Static batch copper exchange capacity for AXIONIT BPA and Dowex M-4195

\begin{tabular}{|c|c|c|}
\hline Sorbent name & Volume of the sorbent $\left(\mathrm{V}_{\text {resin }}\right), \mathrm{ml}$ & SEC $(\mathrm{Cu}), \mathrm{mg} / \mathrm{ml}$ \\
\hline AXIONIT BPA & 1.774 & 36.87 \\
\hline AXIONIT BPA & 6.052 & 35.11 \\
\hline Dowex M-4195 & 1.923 & 34.94 \\
\hline Dowex M-4195 & 6.503 & 35.40 \\
\hline
\end{tabular}


The solution from the outlet of the column every hour using collector fraction were sampled by $50 \mathrm{ml}$ of a solution corresponding to $0.5 \mathrm{BV}$. Each fraction was analyzed for copper content by mass spectrometry. From the data obtained, the output curves of copper sorption were plotted (Figs. 5 and 6 ), and the values of the dynamic exchange capacity and the full exchange capacity were calculated using formulas (2) and (3), respectively. The results are shown in Tables 3 and 4.

\section{Water wash of the load resin}

Since the concentration of silver in the electrolyte is quite high, with insufficient quality washing, silver inevitably enters the desorbate in the form of an ammonia complex, which creates the need for further separation of copper and silver.

To determine the optimal volume of water required for washing the sorbent from electrolyte residues, the saturated sorbent (Axionit BPA) was washed from the model electrolyte solution. Water was fed into the column from top to bottom at a rate of $5 \mathrm{BV} / \mathrm{h}$ for 2 hours. At the outlet of the column using fraction collector the samples of the washing solution with a volume of 2 BV were taken and precipitate of silver chloride was deposited by the addition of $\mathrm{HCl}$ to the samples. The copper concentration in the samples of thesolution from water wash step was determined by the ICP method, and the silver concentration was determined by the gravimetric method. The experimental results are presented in Table 5.

\section{Desorption}

For desorption, we used an AXIONIT BPA sample saturated with copper under dynamic conditions from a model solution (section 3.2) and washed with 10 column volumes of water.

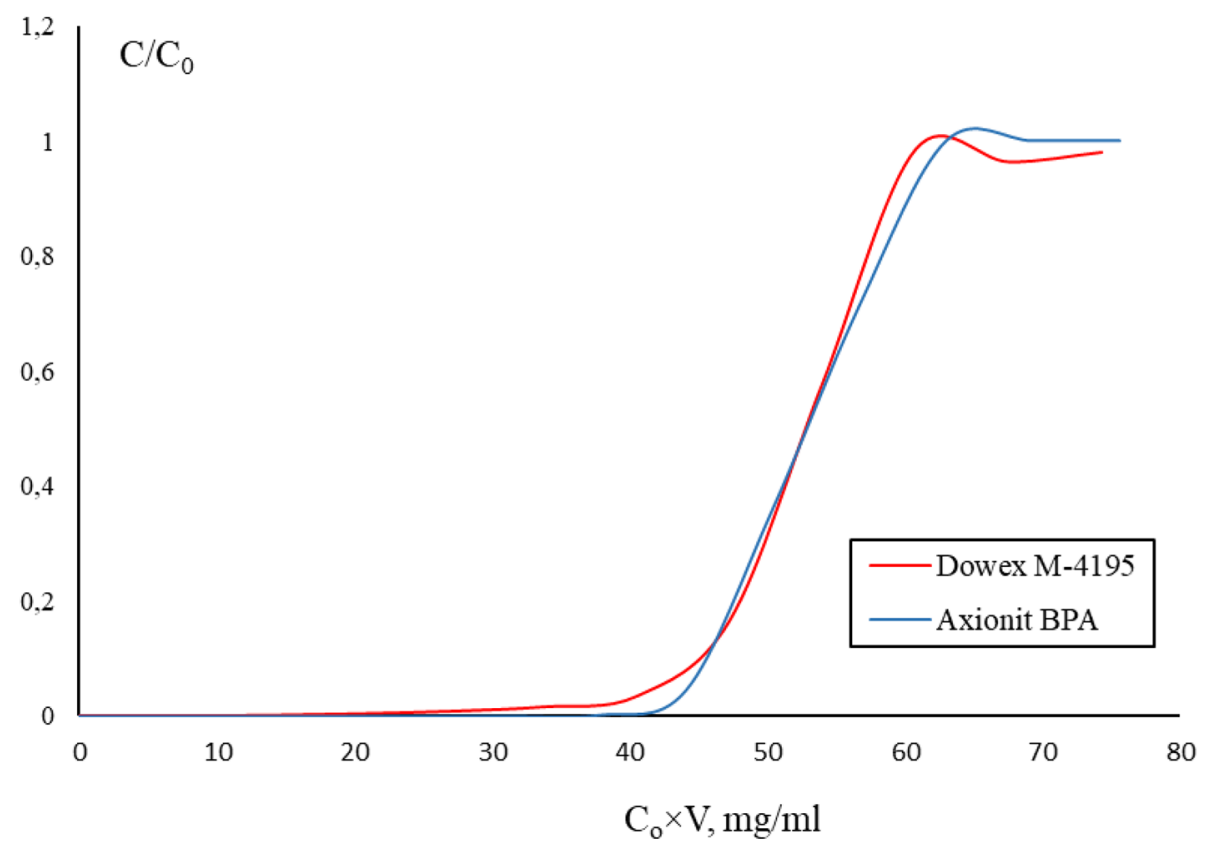

Fig. 5. Output curves of copper sorption on AXIONIT BPA and Dowex M-4195 resins. Feed: Ag - $180 \mathrm{~g} / \mathrm{l}, \mathrm{Cu}-$ $13 \mathrm{~g} / \mathrm{l} . \mathrm{T}=25^{\circ} \mathrm{C}$., Flow rate $1 \mathrm{BV} / \mathrm{h}, \mathrm{pH}=2$ 


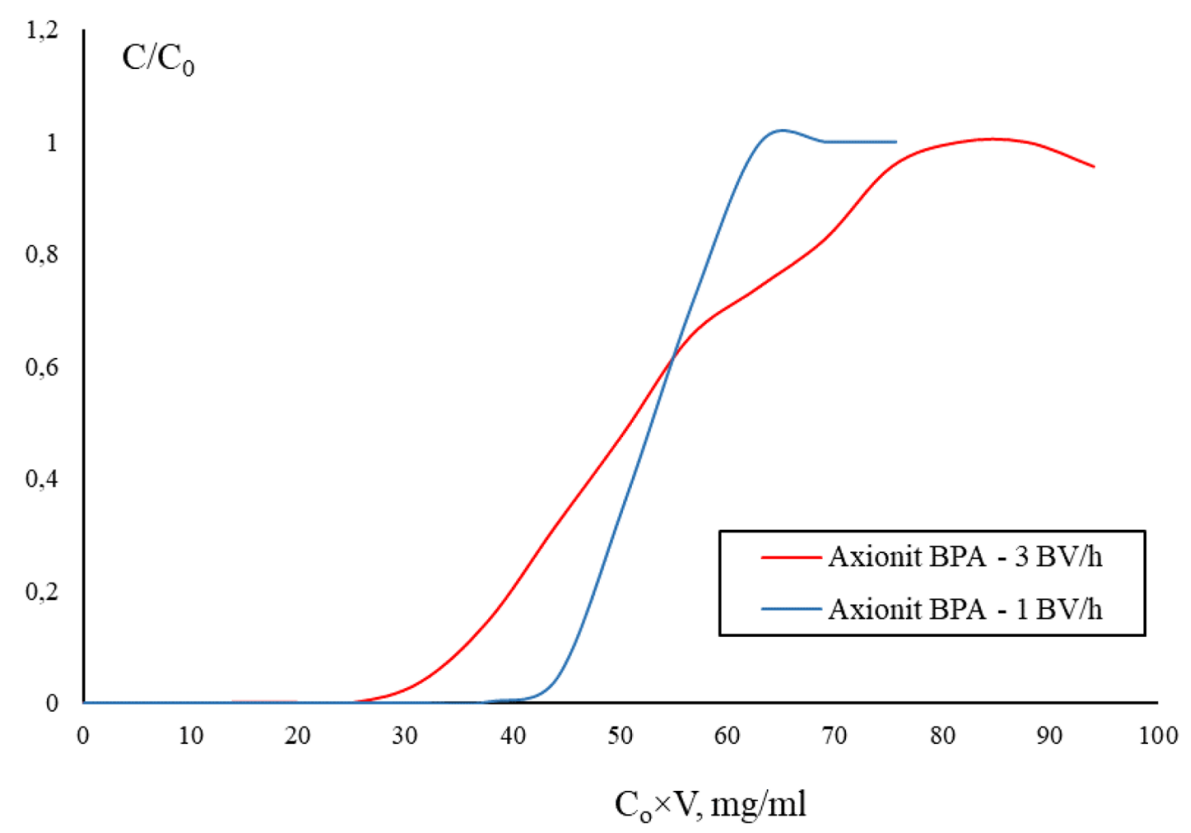

Fig. 6. Output curves of copper sorption on the Axionit BPA. Feed: $\mathrm{Ag}-180 \mathrm{~g} / 1, \mathrm{Cu}-13 \mathrm{~g} / 1 . \mathrm{T}=25^{\circ} \mathrm{C} \cdot \mathrm{pH}=2$. Flow rate $1 \mathrm{BV} / \mathrm{h}$ and $3 \mathrm{BV} / \mathrm{h}$.

Desorption of copper with AXIONIT BPA was carried out in four ways: $3 \%, 5 \%, 10 \% \mathrm{NH}_{4} \mathrm{OH}$, as well as two-stage desorption with $5 \%$ and $10 \% \mathrm{NH}_{4} \mathrm{OH}$ solution was carried out at a solution feed rate into the column of $2 \mathrm{BV} / \mathrm{h}$. In all experiments, the ammonia solution was fed into the column with the sorbent from above. The experiments were carried out with the selection of fractions of $0.5 \mathrm{BV}$. The resulting desorbatessolutions were analyzed for copper and silver content measuring. The data obtained were used to plot the output curves of copper desorption (Figs. 7 and 8).

\section{Results and discussion}

\section{Sorption under static conditions}

An experiment on the sorption of copper under static conditions showed that both samples are capable of recovering copper from a model solution of a silver electrolyte with $\mathrm{pH}=2$. Table 2 shows the obtained values of the static exchange capacity for both samples. Capacities for both samples have similar values $(35-36 \mathrm{mg} / \mathrm{ml}$ ), and also correspond to the capacity declared by the manufacturer (Dow Chemical Company) for copper at $\mathrm{pH}=2: 35-42 \mathrm{mg} / \mathrm{ml}$.

\section{Sorption under dynamic conditions}

Despite the close values of FDEC for both samples: $49.0 \mathrm{mg} / \mathrm{ml}$ for Dowex M-4195 and $49.6 \mathrm{mg} / \mathrm{ml}$ for Axionit BPA (Table 3), in the second case, the solution at the column outlet before breakthrough (2.5 BV) contains less than $10 \mathrm{mg} / 1$ of copper, while the average concentration of copper in the first 2.5 column volumes of the solution in the case of Dowex M-4195 was $75 \mathrm{mg} / 1$.

Just as can be seen from the graph of the sorption output curves (Fig. 5), in the case of sorption on Dowex M-4195, after reaching the capacity of $30 \mathrm{mg} / \mathrm{ml}$, small slip-throughs in copper are observed. 
In the case of AXIONIT BPA, early breakthroughs were not observed, therefore, it was possible to purify a larger volume of the initial solution.

\section{Effect of the flow rate on purification performance}

An experiment on the saturation of AXIONIT BPA with copper at a feed rate of the solution to be purified into the column of 1 and $3 \mathrm{BV} / \mathrm{h}$ shows that the rate of absorption of copper ions by the sorbent in this rate range is strongly limited. With an increase in the feed rate of the solution from 1 to $3 \mathrm{BV} / \mathrm{h}$, the volume of the solution purified from copper decreased by half (from $3 \mathrm{BV}$ to $1.5 \mathrm{BV}$ ). The dynamic exchange capacity at the supply of $3 \mathrm{BV} / \mathrm{h}$ was $18.8 \mathrm{mg} / \mathrm{ml}$ (Table 4).

Thus, for the purification of silver electrolyte from copper, the most optimal flow rate of the solution to the column is no more than $1 \mathrm{BV} / \mathrm{h}$ (Table 4).

\section{Water wash of the load resin}

The experiment on washing the sorbent saturated with copper from the electrolyte shows that for effective washing from silver, at least 6.5 column volumes of water must be passed through the sorbent, after which the washing efficiency decreases (Table 5).

Table 3. Copper dynamic exchange capacity and full dynamic exchange capacity of Dowex M-4195 and AXIONIT $\mathrm{BPA}$ studied for removal $\mathrm{Cu}$ from the $\mathrm{AgNO}_{3}$ electrolyte

\begin{tabular}{|c|c|c|}
\hline Sorbent & DEC, $\mathrm{mg} / \mathrm{ml}$ & FDEC, $\mathrm{mg} / \mathrm{ml}$ \\
\hline Dowex M-4195 & 33.6 & 49.0 \\
\hline Axionit BPA & 37.9 & 49.6 \\
\hline
\end{tabular}

Table 4. The effect of the flow rate on the dynamic sorption capacities of $\mathrm{Cu}$ using AXIONIT BPA for removal of $\mathrm{Cu}$ from the $\mathrm{AgNO}_{3}$ electrolyte

\begin{tabular}{|c|c|c|}
\hline Sorbent & DEC, mg/ml & FDEC, $\mathrm{mg} / \mathrm{ml}$ \\
\hline AXIONIT BPA 1 BV/h & 37.9 & 49.6 \\
\hline AXIONIT BPA 3 BV/h & 18.8 & 49.5 \\
\hline
\end{tabular}

Table 5. The concentration of silver in the fractions of washing water. Flow rate $5 \mathrm{BV} / \mathrm{h}$

\begin{tabular}{|c|c|c|}
\hline $\begin{array}{c}\text { Volume of water passed through } \\
\text { the column, BV }\end{array}$ & Volume of fraction, BV & C $_{\text {Ag }}$ in fraction, mg/ 1 \\
\hline 0,5 & 0,5 & 179940,0 \\
\hline 2,5 & 2,0 & 8046,0 \\
\hline 4,5 & 2,0 & 447,0 \\
\hline 6,5 & 2,0 & 306,5 \\
\hline 8,5 & 2,0 & 16,8 \\
\hline 10,5 & 2,0 & 18,2 \\
\hline
\end{tabular}




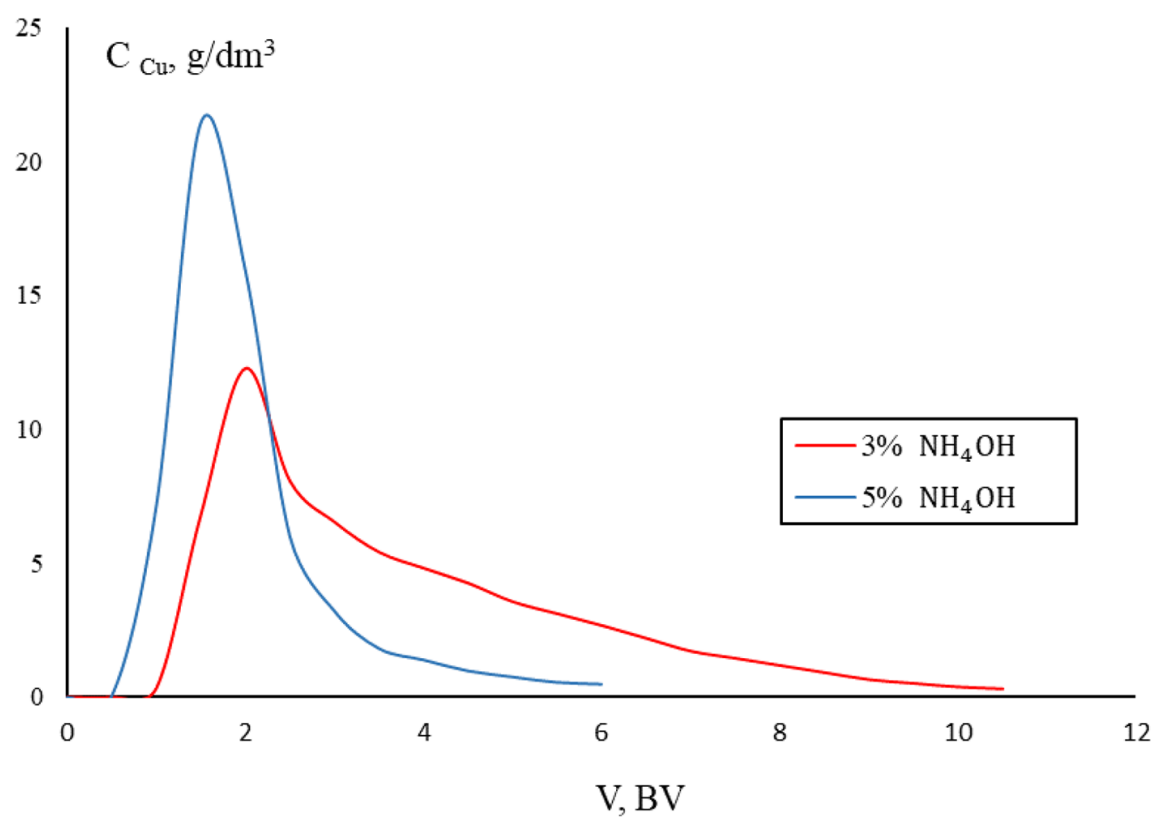

Fig.7. Output desorption curves of copper from AXIONIT BPA $3 \%$ and $5 \% \mathrm{NH}_{4} \mathrm{OH}$ at volume rate $2 \mathrm{BV} / \mathrm{h}$

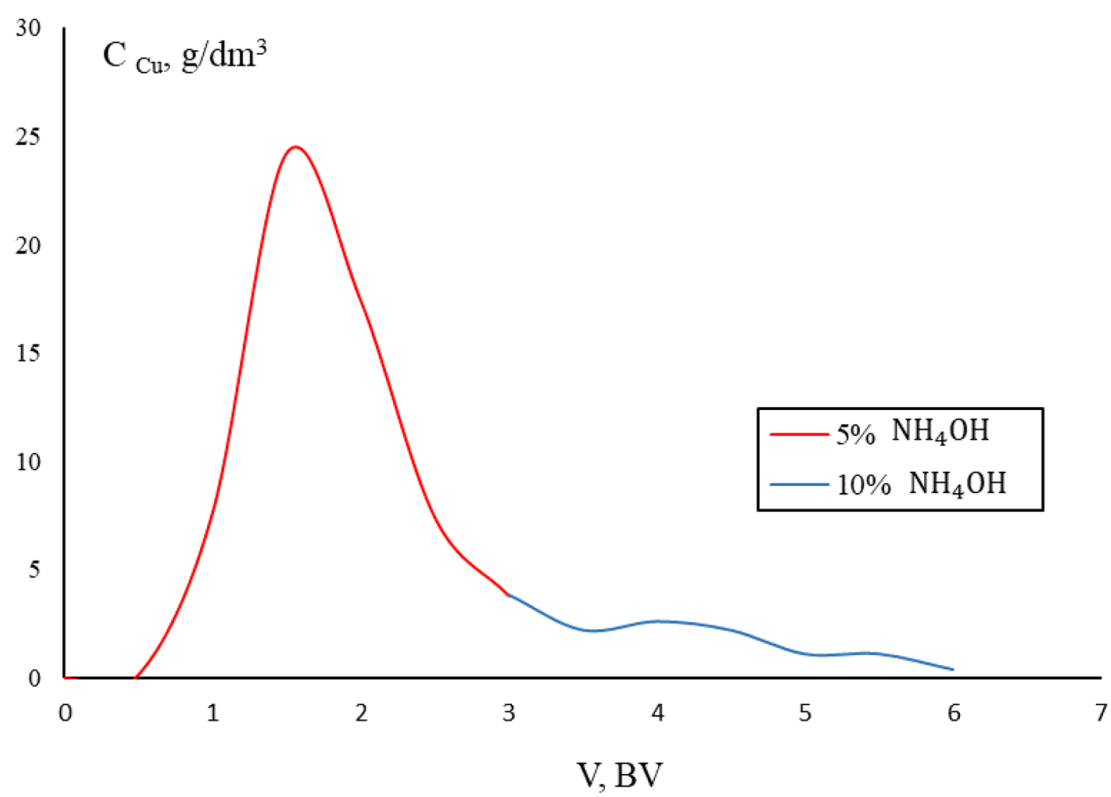

Fig.8. Output curves of two-stage copper desorption of $5 \%$ and $10 \% \mathrm{NH}_{4} \mathrm{OH}$ at volume rate $2 \mathrm{BV} / \mathrm{h}$

\section{Desorption}

The results of desorption with $3 \%$ and $5 \%$ ammonium hydroxide solutions showed that copper desorption occurs most completely in the presence of a $5 \% \mathrm{NH}_{4} \mathrm{OH}$ solution (Fig. 6).

During desorption of $5 \% \mathrm{NH}_{4} \mathrm{OH}$, a crystalline precipitate of $\left[\mathrm{Cu}\left(\mathrm{NH}_{3}\right)_{4}\right]\left(\mathrm{NO}_{3}\right)_{2}$ was found in the desorbate fractions containing more than $10 \mathrm{~g} / \mathrm{l}$ of copper. Desorption of $10 \% \mathrm{NH}_{4} \mathrm{OH}$ was also 
carried out, but due to the precipitation of a precipitate directly in the column, the experiment could not be completed. Apparently, this is due to the limited solubility of tetraamine copper (II) nitrate. It was not possible to find exact data on the solubility of $\left[\mathrm{Cu}\left(\mathrm{NH}_{3}\right)_{4}\right]\left(\mathrm{NO}_{3}\right)_{2}$ in the reference data. The degree of desorption of copper 3 and $5 \% \mathrm{NH}_{4} \mathrm{OH}$ wasn't more than $90 \%$.

A two-stage copper desorption was also carried out, first with three column volumes of $5 \%$ $\mathrm{NH}_{4} \mathrm{OH}$, then with three column volumes of $10 \% \mathrm{NH}_{4} \mathrm{OH}$ (Fig. 7), which turned out to be the most effective. Thedegreeofcopperdesorptioninthisexperimentwas $95.8 \%$.

Fractionation of the obtained desorbate by 3 column volumes into two fractions made it possible to obtain copper-rich, with $\mathrm{Cu}$ content $-10.1 \mathrm{~g} / \mathrm{l}, \mathrm{Ag}-53 \mathrm{mg} / \mathrm{l}$, and poor: $\mathrm{Cu}-1.61 \mathrm{~g} / 1, \mathrm{Ag}-11.2 \mathrm{mg} / \mathrm{l}$. The lean fraction can be reused in a subsequent cycle at the first stage of desorption, and copper hydroxide is supposed to be precipitated from the rich fraction with preliminary purification of the desorbate from silver, precipitation of $\mathrm{AgCl}$. According to the formula (5), the separation coefficient of copper and silver in dynamic conditions $D_{C u, A g}=2598$ is calculated from the concentrations of copper and silver ions in the initial solution and in the rich desorbate fraction.

\section{Conclusion}

The ability of two commercial sorbents AXIONIT BPA and Dowex M-4195 to extract copper from a model solution of a silver electrolyte to residual copper concentrations of less than $10 \mathrm{mg} / \mathrm{l}$ was studied. The capacity of the sorbent for copper under static batch conditions was determined, which was $35 \mathrm{~g} / 1$ and the total dynamic exchange capacity was $49.6 \mathrm{~g} / 1$. A study of the effect of the feed rate of the solution being purified on the sorption of copper showed that an increase in the feed rate of the solution from $1 \mathrm{BV} / \mathrm{h}$ to $3 \mathrm{BV} / \mathrm{h}$ leads to a 2 -fold decrease in the yield of the solution purified from copper. The washing experiment showed that for effective separation, it is necessary to wash the sorbent after saturation with $6.5-10$ column volumes of water. Studies on the desorption of copper with $3 \%$ and $5 \%$ ammonium hydroxide solution under dynamic conditions have shown that no more than $90 \%$ of copper is desorbed in this way. A two-stage scheme of copper desorption is proposed, first $5 \%$, then $10 \% \mathrm{NH}_{4} \mathrm{OH}$, which allows desorbing more than $95 \%$ of copper. The separation coefficient of copper and silverin dynamic conditions $D_{C u, A g}=2598$ is calculated.

\section{References}

1. Mining of precious metals. Information and technical guide to the best available technologies. Federal Agency for Technical Regulation and Metrology. Moscow, 2017.- 143 p.

2. Gao, J., LiuF., Ling P., Lei, J., Li L., Li, C., Li. A., High efficient removal of Cu(II) by a chelating resin from strong acidic solutions: Complex formation and DFT certification. Chemical Engineering Journal. 2013. Vol. 222. P. 240-247 [in Rus.].

3. Zakhar'ian S. V. Karimova L. M. Naboichenko S. S. Rogozhnikov D. A. Sorption extraction of copper on LewatitMonoplus TP-200 ionite from solutions of nitric acid leaching of copper concentrate. Vestnik IrGTU. 2018. Vol. 22(6). P. 204-212.] [in Rus.].

4. Kołodyńska, D., Sofińska-Chmiel W., Mendyk E., Hubicki.Z. DOWEX M 4195 and LEWATIT® MonoPlus TP 220 in Heavy Metal Ions Removal from Acidic Streams. Separation Science and Technology. 2014. Vol. 49. P. 2003-2015. 
5. Grinstead, R.R. Selective absorption of copper, nickel, cobalt and other transition metal ions from sulfuric acid solutions with the chelating ion exchange resin XFS 4195. Hydrometallurgy. 1984. Vol. 12. P. 387-400.

6. Neto, I. F. F., Sousa C. A., Brito M. S. C. A. Futuro A. M., Soares H. M. V. M. A simple and nearly-closed cycle process for recycling copper with high purity from end life printed circuit boards. Separation and Purification Technology. 2016. Vol. 164. P. 19-27.

7. Zhu, Y. Millan. E., Sengupta A. K. Toward separation of toxic metal(II) cations by chelating polymers: some noteworthy observations. Reactive Polymers. 1990. Vol. 13. P. 241-253.

8. Dinz, C. V., Ciminelli V. S. T. Doyle F. M. The use of the chelating resin Dowex M-4195 in the adsorption of selected heavy metal ions from manganese solutions. Hydrometallurgy. 2005. Vol 78. P. 147-155. 